\title{
Exploitation and alienation of the body of the nurse: a phenomenological study*
}

\author{
A exploração e alienação do corpo da enfermeira: um estudo fenomenológico \\ Explotación y alienación del cuerpo de la enfermera: un estudio fenomenológico
}

Leomar Albini ${ }^{1}$, Liliana Maria Labronici ${ }^{2}$

\begin{abstract}
Objective: To understand the experience of being woman, mother, and nurse. Methods: This phenomenological study was conducted in a teaching hospital in Curitiba, Brazil from June 2005 to March 2006. The sample consisted of seven nurses. Data were collected through semi-structured interviews. Results: The main emerged theme was "Exploitation and alienation of the body of the nurse until its exhaustation." Conclusions: Nurses have difficulties in assuming other roles in professional organizations and institutional administration due to workload and exhaustion in performing their personal and professional tasks.
\end{abstract}

Descritores: Women; Women's work; Nurses; Hospitals

\section{RESUMO}

Objetivo: Compreender como o corpo feminino se percebe ao vivenciar a experiência do ser mulher, mãe e enfermeira. Métodos: Estudo fenomenológico realizado em hospital de ensino público de Curitiba- PR, de junho de 2005 a março de 2006, com sete enfermeiras. Os discursos foram obtidos mediante entrevista semi-estruturada gravada. Resultados: O tema destacado é: A exploração e alienação do corpo da enfermeira levando à exaustão. Conclusões: Os discursos expressam a dificuldade das enfermeiras assumirem outras funções junto a órgãos de classe, administração da instituição, em virtude da sobrecarga e da exaustão a que estão submetidas no cotidiano pessoal e profissional.

Descritores: Mulheres; Trabalho feminino; Enfermeiras; Hospitais

\section{RESUMEN}

Objetivo: Comprender cómo se percibe el cuerpo femenino al vivenciar la experiencia del ser mujer, madre enfermera. Métodos: Se trata de un estudio fenomenológico realizado con siete enfermeras en un Hospital de enseñanza público de Curitiba-Paraná, de junio del 2005 a marzo del 2006. Los discursos fueron obtenidos mediante entrevista semi-estructurada grabada. Resultados: El tema destacado es: La explotación y alienación del cuerpo de la enfermera llevando al agotamiento. Conclusiones: Los discursos expresan la dificultad de las enfermeras para asumir otras funciones junto a órganos de clase, administración de la institución, en virtud de la sobrecarga y del agotamiento al que están sometidas en el cotidiano personal y profesional.

Descriptores: Mujeres; Trabajo femenino; Enfermeras; Hospitales

\footnotetext{
* This article is part of a Masters Thesis from the Parana Federal University - Nursing Graduate Department, study carried out in a Public Hospital in Curitiba.

${ }^{1}$ MNS, Nursing in Transfunctional Comit in Clinic Hospital by the Parana Federal University - UFPR - Curitiba (PR), Brazil.

${ }^{2}$ Associate Professor at the the Parana Federal University - Nursing Department - UFPR - Curitiba (PR), Brazil.
} 


\section{INTRODUCTION}

The twentieth century was a stage of victory for women in the world, whose major challenge was conquering equal rights, guaranteeing women's right to be respected as human beings, daring a system of representations based on men's domination over women, the patriarchy ${ }^{(1)}$.

Women's key challenge is to remain in the work market and conciliate with their private life, so as to meet the several requirements of the public and private worlds ${ }^{(2)}$. Being a woman, mother, and professional strongly interferes in women's everyday life, which demands them to balance between the private and public worlds ${ }^{(3)}$. This leaves them little time for being a woman. Furthermore, this fact is aggravated by the social demands that impose not a double, but triple shift over them. This insertion into the public world began with professions as nursing and teaching; functions that concern caring and teaching, related to the family universe. It is as if the hospital, for nursing, were similar to a large home whose management and organization demands were nurses' responsibilities: a mixture of mother and professional ${ }^{(4)}$. As a consequence, the two spheres, public and private, are confused, making women unable to tell them apart. For this reason, nursing has been characterized as an extension of domestic work ${ }^{(5)}$.

From this perspective, nursing becomes a socially undervalued activity, besides having to carry the burden of a predominantly feminine profession. Low pay is also a problem, which, allied with the daily difficulties, force many nurses to have two jobs.

Over time, nursing became the category that represents the largest work force in health care. In the hospital setting, this category and its respective activities are frequently marked by a fragmented division of tasks, a rigid hierarchic structure regarding work routine, norms, and regulations, in addition to a short and unqualified staff. This has resulted in high absenteeism rates and illness leaves ${ }^{(6)}$. Moreover, in this setting, nurses' bodies are often confused with a mere work instrument, so they work double or triple shifts to compensate for their low salaries $^{(7-8)}$. In addition, their perception of stress is often affected by external factors like work, family, and the environment; as well as by internal factors like emotions, previous experiences, beliefs, and values ${ }^{(9)}$. Nurses' movements of going and coming from the private to the public world can reveal a multifaceted reality. This could contribute in the process of rethinking nurses' being and living in the world in this triad.

Thus, the purpose of this study is to "Understand how the female body is perceived when going through the experience of being a woman, nurse, and mother in the hospital setting considering the triple work shift". This study was founded on the philosophical framework by
Maurice Merleau-Ponty about the body.

\section{Ponty \\ The body from the view of Maurice Merleau-}

Man is understood as being a body, the vehicle of all relations with the world ${ }^{(7)}$. The embodied conscience is the concrete human existence and the corporeity of human expression. Hence, corporeity is humans' way of being, it is letting flow, thinking, feeling, planning not only based on results, but also on feelings, desires, and ideals; it is assuming the human condition founded on freedom and human needs. Corporeity evidences the possibility of being a body, the appropriation of countless discontinuous acts, significant elements that surpass and transform the natural form of a body ${ }^{(8)}$.

It is important to highlight that it is through the body that man is equitable toward the world, and becomes aware that all things coexist with the embodied subject. It is through the body that man understands "others and things". Thus, the problem of the world, and, to begin with, of the body per se, consists in the fact that all resides there. An individual is his/her body exactly as knowledge is obtained and, reciprocally, the body is a natural subject, as a temporary draft of one's total being ${ }^{(7)}$.

Being a body means being attached to the world. This, according to the existential phenomenology of MerleauPonty, translates into evidencing the body as a place of perception of the experienced world, considering that perception is what transports man to existence in the most complete sense. The body comprises intention and feeling; it acts toward the world from existence; it is the concrete existence, established on the facticity of life and of the world. For the philosopher "I have no body, I am my $\operatorname{body}^{\prime(7)}$.

\section{METHODS}

The quest for understanding the phenomenon was the motivation for choosing the phenomenological research. Phenomenology is a description of the specific structure of the time flow of experiences and the ability to assign meaning to external things constituting consciousness, understood as phenomenon. Thus, focused on experience, phenomenological reflection comprises the possibility of looking at things as they are manifested. Through experience, the world opens to man, and this opening, this unveiling, is the phenomenon ${ }^{(10)}$.

This research was developed in critical care units (adult and pediatric intensive therapy care, units for hematopoietic stem cell transplants, adult and pediatric emergency, neonatology and emergency service) of a public teaching hospital in Curitiba (Parana State, Brazil), from June 2005 to March 2006. Inclusion criteria included: being a registered nurse providing patient care, having 
worked with critical care for at least five years, having two registered jobs, and having children, regardless of their marital status. Interviews were performed with seven nurses, with ages between 32 and 48 years, and with 14 to 20 years of nursing experience. Two of the nurses have an only child, four have two children, and one has three children. Nurses' children's ages ranged between 2 and 16 years. One nurse is divorced, five are married, and one is single.

The number of participants was determined by their own content in the statements, which demonstrated richness regarding the definition of the phenomenon and were, therefore, sufficient for the study proposal.

In terms of ethics, this study was approved by the Institutional Review Board. Next, a first approach was made toward nurses who met the established criteria. The study proposal was presented and they were invited to participate as collaborators. Next, after reading the informed consent form, all questions were answered and participants provided two copies of written consent to make their participation official. The statements were identified with Arabic numerals from one to seven, as per the interviews were carried out. In this same meeting, the place and time of the interviews were scheduled. All interviews were carried out in a private location so nurses' activities would be the least interfered. All nurses chose to be interviewed at their work sites.

During the interviews, the following request was used to encourage nurses to give their statements: Tell me about how you see yourself as a woman, professional, and mother in your everyday life. With the aim to understand the phenomenon, this study complied with the recommendations for phenomenological interviews; that is, a quiet and private place was provided for an appropriate approach, thus contributing with empathy. Immediately after obtaining the statements, the interviews were integrally transcribed, with the aim of verifying if the nurses' delineations answered the questions. Efforts were made to preserve subjects' ideas, language, repetitions, pauses, and demonstrations of emotion. The material obtained individually was handed to each nurse in person, so they could be informed about the complete description, so as to avoid further problems related to any kind of content distortion. They were allowed to, if necessary, complement the transcription and/or make it partially or integrally unavailable. However, there were no requests for changes in their statements.

Analysis was carried out following the phenomenological line of thought, which consist of three moments: describing, reducing, and phenomenological understanding ${ }^{(9)}$.

The description is the simple exhibit of a phenomenon. It takes the form of text to be analyzed, interpreted, and understood. This means the purpose is to search for essence and transcendence.

Reduction is the moment when a selection is made from the subjects' integral statement, obtaining the excerpts considered essential to understanding the phenomenon. The excerpts are kept original, that is, free from prejudgments and prejudice. That is, these fragments are referred to as units of meaning ${ }^{(11)}$.

Phenomenological understanding emerges along with interpretation, and is only possible when the subject's perception regarding the phenomenon is unveiled. Efforts are made to transform the study subjects' statements into a language that would sustain the search, which translates into "an educational or social psychological statement" (11). Finally, a synthesis of the units of meaning is organized, involving all the study subjects. This synthesis originates one or more themes or categories.

The themes which emerged in this study were: "The challenge of being a woman and mother amongst the multiple roles taken" and "The exploitation and alienation of the body, leading to exhaustion".

This study presents the analysis of the theme: "The exploitation and alienation of the body, leading to exhaustion".

\section{RESULTS}

Perhaps women's first job was to look after their children. Next, there was the incorporation of house work, full of unexpected changes that required women to plan or re-plan their activities. Each moment, the "priority order is totally determined by the woman performing the activities, as well as the work process and the instruments used", which makes women outstanding administrators ${ }^{(12)}$. However, when women begin their professional lives, the fact that largely interferes in their participating in the work market is that they have multiple functions that sum up with taking care of their children and their home. That, in addition to the lack of structure, like daycare, limits their leaving the home toward the remunerated work market ${ }^{(13)}$. This multiplicity of roles strongly affects women's daily activities, and demands them to balance between the two worlds ${ }^{(14)}$. The problem is worsened by the current social demands, which imply women take on not a double, but triple work shift.

The specificity of care as a feminine work assigns special characteristics to nurses and their work: care is an extension of housework; it is invisible, subjective, and socially undervalued; the development of women's work shift, which begins at home, continues at work, and ends at home again, does not include weekly rest, nor paid vacations ${ }^{(15)}$. None of these tasks helps to increase working-women's self-esteem. Rather, they lead to chronic fatigue and both physical and mental exhaustion. Hence, the body symbolizes existence, because it is its reality ${ }^{(7)}$; and these exhausted bodies express their realities in the 
following excerpts:

I work every weekend, sometime I have a break and I stay bome for twelve hours, but I never stay home for twelve hours, so there's no way I can give my children the attention I'd like to give. (3)

I think I take most stress into the house, I know it's wrong, but when I realize it, it's done [...] you know that minute you want and your kids want your attention and you say: give me a break. son. (4)

Nurses are often subject to inappropriate work conditions, which are health hazardous and could have physical or psychological outcomes, causing eating, sleep, and elimination disorders, in addition to fatigue, decrease in alert state, family disorganization, and neurosis. These facts often lead to occupational accidents and work leaves for health treatments, in addition to a high absenteeism rate.

Concurrently, there is the issue of low pay allied to daily difficulties, which encourage many nurses to search for another better-paying job. This means nursing staff have work overload, and compromised sleep- and resthours, which are essential to every human being ${ }^{(16)}$.

This is especially highlighted in the hospital setting, where nursing represents the largest work force, and their activities are often marked by a fragmented task division, a rigid hierarchic structure regarding work routine, norms, and regulations, in addition to a short and unqualified staff. This has resulted in high absenteeism rates and illness leaves $^{(6)}$.

Psychosocial risks, often underestimated by the institution, are caused by contact with patient suffering, and the accumulation of activities that lead to stress, mental fatigue, and emotional disorders. Ergonomic problems are largely developed by irregular body posture in situations like moving patients, frequent back flexions, and others $^{(17)}$. In addition, it should be stressed that operational issues associated with the hospital setting, like working in shifts to provide continuous 24-hour service, interferes in family life. This interference is even more intense when nurses have more than one job ${ }^{(18)}$.

Another important factor is that working in closed units and critical areas, due to their complexities, demands agility of nurses when making decisions, as well as critical thinking, leadership skills, and acquiring intellectual abilities. Nonetheless, nurses' reality is imprecise, covered with polyvalent undetermined activities, which incorporates the historical invisibility of feminine work, resulting in a lack of encouragement to develop their daily activities ${ }^{(19-20)}$.

Even professionals who work with us can't differentiate, to them we are all nurses, they don't value, for them what's important is that someone goes there do give the patient a bath, and give them their medication. (3)
If you do it, you did nothing besides your obligation, if you forgot to do it once, you are no longer a good professional, you are not respected, there are many people that, including the clients we have, for them everyone is a nurse. (7)

In the above statements, it can be observed that nurses perceive themselves as undervalued, both by the staff as by those they provide with healthcare services. Their actions are not clear and specific of a specialist professional, so they end up confused with the routines and actions of other nursing staff members. In addition, they answer to others' orders, which can translate into an anonymous and passive existence, in which these nurses' bodies become their "hideaway from life" (7).

In this sense, it is observed that nursing has inherited certain difficulties that are hard to unleash from, while making an existential movement toward the world, the future, and restarting ${ }^{(7)}$. Defined as a feminine profession and built on a patriarchal structure, nurses have been taught not to fight for space and power ${ }^{(19)}$. Power is not a natural object, a thing; it is a social practice, which takes place amongst relationships ${ }^{(21-22)}$. Power is associated with knowledge and competency, and reflects on force and acceptance of one's opinion regarding institutional decisions $^{(23)}$. In this study, it is observed that nurses have a disciplinary power delegated by their position in the nursing staff, but they have no institutional power. Changes in this overview involve increasing nurses' knowledge and competency, which would provide them with a stronger influence in the health area and reduce the distance between other healthcare professionals. Similarly, it appears that besides the technical competency to build power relations, nurses should develop political competencies and specific scientific knowledge; otherwise, they will become professionals that simply accomplish tasks and medical orders, while other professionals manage healthcare ${ }^{(24)}$. This situation, allied with the work overload, favors nurses' precarious organization. Hence, it is visualized that by accumulating multiple work shifts, nurses become less available and increasingly more distant from a conscientious and participative practice of their profession, which makes them even more fragile regarding the power-knowledge relation.

Work is not exclusively responsible for a worker's unhappiness or happiness. What happens during their offduty hours affects their health condition and their performance at work ${ }^{(25)}$. However, for nurses who participated in this study, there is insufficient time for other activities, since they focus their scarce "free time" in housekeeping and looking after their children. Leisure, on the other hand, though an important issue for existential development, does not exist. This is observed in the statements: 
Every break I felt I had to stay with my family, I didn't think it was right to go out without them. (1)

I don't go out, I don't go for a walk, I don't go anywhere, I life for my work and home. (3)

In fact, today, promises of leisure and rest render as a society consumed by work, in which post-modernity bears the inheritance of endless work from modern times. This is despite the promises from a futurist perspective that in the $21^{\text {st }}$ century, activities would be performed by machines, a product of knowledge built for centuries by man. As a consequence, man would break free from slavery due to work. This encourages the thought of how history repeats itself, considering that, in the beginning of the $20^{\text {th }}$ century, it was common for people to work 14 to 15 hours a day.

Society has caused people to become so deeply involved with work, to the point that besides their selfabdication and renouncing all that surrounds them, there is a feeling of guilt for not having good health conditions and, hence, not being able to adequately perform their activities. The capitalist society establishes that production is what matters; keeping healthy to produce more each day:

[...] and there's that thing, nurses don't get sick, it's just whining, it's not illness, because even colleagues demand from you, you see nurse colleagues who are having a breakdown, who need help, who are anxious [...], they have a lot of issues and aren't worried about it, because apparently it's still working, isn't it? They're working. (2)

[...] I go to the dentist when I can, to the doctor only when my work demands it, I had a problem with my leg and I had to get a doctor's statement, I couldn't, but leave to get a check-up isn't possible, just after you're sick, it's been about three years I don't go to the gynecologist, there's no time. (4)

The way these caretaker bodies care for or neglect themselves is related to the condition of testing their limits, of trying to prove that even with two jobs, there is no reduction in "productivity", whatever it takes. It would be ideal for each woman to respect their restrictions and, at the end of the day, enjoy their needed rest dedicating a few hours to their families and themselves. Since the body is a being's vehicle in the world, it can take on new forms of existing and continuously work on them ${ }^{(7)}$. However, in this study, it was observed that these caretaker bodies do not allow themselves any time. Work is their top priority, and there is no time for noticing their body's alert signals. Moreover, work activities lose the meaning of pleasure and become suffering and illness, ensuing low self-esteem. The apathetic form of keeping oneself busy eventually interferes on care-related relations either toward patients, family, friends, or colleagues. This is shown in the following statements:
[...] we have good structure to offer support, a point of view concerning the hospitalizedpatient, and, sometimes, we dodge a little, maybe because of the tiredness. (2)

$[\ldots]$ all this work. load, all these emotional problems, all the illness, dealing with death, dealing with colleagues, dealing with the boss, I think I'm going crasy. (7)

The image that comes to mind is one of solitary people, consumed with excessive work and responsibilities, with no time for resting, for leisure, or for thinking about their own life. This form of existence can result in errors, silence, internal conflicts, and a distancing from the world.

These positions stem from a group of factors, including each professional's individuality, the remnant nursing historicity marked by many things including subalternity, and yet others that originate from organizational issues as well as the existing healthcare and administrative models of health service facilities ${ }^{(26)}$.

Changing the form of being-in-the-world is not easy. First, self-perception and self-conscience is required to establish a relationship with others and with the world. Each person's existence and everything they are is founded on a situation that is made their own. That situation is constantly changed by a sort of regulation that is never an unconditioned freedom ${ }^{(7)}$.

I intend to do some specialization, I still haven't managed to do it, in these 14 years, I practically worked in two jobs all this time. (1)

I only read, study, after my danghter goes to bed, I have to participate in congresses, whatever is related to my job I do it, I have to do it, I have to do this, I can't be a little robot professional (6)

Generally, nurses demonstrate their awareness regarding the need to update, but they report there is no interest and support from the institution in terms of human resource development and improvement. Working in shifts and performing activities in two jobs makes it difficult for the staff to report to the hospital besides in their normal duty hours, which requires creativity and interest from the institution to improve and develop their personnel. It is assumed that knowledge construction takes place through life and through formal or informal relationships, which require disposition and interest. Otherwise, nurses are in risk of remaining immobilized to their daily professional work, repeating routines and procedures with no competency and motivation to interfere in the experienced reality.

By setting out for knowledge, nurses return to work with a proactive conduct. Behaviors generate meanings, since there are taught and learned. Thus, nurses acquire the capacity to change the experienced reality, and, by promoting guidance to their staff, they develop the visibility of their specific work, leadership, and the 
construction of autonomy in their everyday life ${ }^{(7)}$.

\section{CONCLUSIONS}

A profession as nursing, specifically in the hospital area, poses high demands, especially when nurses work 12 to 16 hours a day in activities involving taking care of others and maintaining life. This undertakes a much greater dimension of concern when caretakers are extremely tired. In this sense, this study questions the quality of the provided health care, since caretakers do not take care for themselves, are tired, worn out. This shows the awareness that human beings should have of themselves to not be destroyed by this system in which everything becomes disposable and impersonal.

Nurses are caretaking bodies responsible for maintaining the lives of other bodies. In this relationship, between caretaking and care-receiving bodies, perceiving others in their different movements of existence is essential in terms of providing quality humane care. In this sense, a question arouses: how can a caretaking body be open to the meaning of others' experiences if it is not able to perceive its own being in the world, not having time to think about its own existence, since it is taken over by an everyday life filled with activities resulting from the accumulation of work shifts?

This study takes a bold step in stating that by allowing themselves to be consumed by work and guilt, and to not be close to their children as much as they would like to be, women make an existential movement toward the past. This way, women have opened their private world to the public world, but, ironically, they have become closed in the latter, as if in a prison.

It is understandable that trying to, alone, change the world or reality is a utopia. Nonetheless, if a network is built, a difference can be accomplished. However, it would imply on individual attitudes and responsibilities, which, if combined, could strengthen the whole, that is, the group.

\section{REFERENCES}

1. Badinter E. Um e o outro: relações entre homens e mulheres. Rio de Janeiro: Nova Fronteira;1986.

2. Fonseca RMGS. Uma leitura generificada da (re)inauguração de um fazer para mulheres: da Inglaterra ao Brasil. Rev Bras Enfermagem. 2002;55(1): 75-84.

3. Spindola T, Santos RS. Mulher e trabalho: a história de vida de mães trabalhadoras de enfermagem. Rev Latinoam Enfermagem. 2003;11(5): 593-600.

4. Moreira MCN. Imagens no espelho de vênus: mulher, enfermagem e modernidade. Rev Latinoam Enfermagem. 1999; 7(1):55-65.

5. Padilha MICS. A mulher / enfermeira nos âmbitos doméstico-familiar e público: uma abordagem teóricocontextual. Rev Gaúch Enferm. 1994; 15(1/2):5-12.

6. Barboza DB, Soler ZASG. Afastamentos do trabalho na enfermagem: ocorrências com trabalhadores de um hospital de ensino. Rev Latinoam Enfermagem. 2003;11(2):177-83.

7. Merleau-Ponty M. Fenomenologia da percepção. 2a ed. São Paulo: Martins Fontes; 1999.

8. Polak YNS. A concepção de corpo no mundo da saúde. Cogitare Enferm. 1996;1(1):4-9.

9. Bianchi ERF. Enfermeiro hospitalar e o stress. Rev Esc Enfermagem USP. 2000;34(4):390-4.

10. Husserl E. Investigações lógicas: sexta investigação (elementos de uma elucidação fenomenolófica do conhecimento). São Paulo: Nova Cultural; 1996. 224p. [Série: Os Pensadores; v. 41.]

11. Martins J. Um enfoque fenomenológico do currículo: educação como poíesis. São Paulo: Cortez; c1992.

12. Rodrigues AM. Lugar e imagem da mulher na indústria. In: Costa AO, Bruschini C, Organizadoras. Uma questão de gênero. Rio de Janeiro: Rosa dos Tempos/ Fundação Carlos Chagas; c1992.

13. Schroeder C, Ward D. Women, welfare, and work: one view of the debate. Nurs Outlook. 1998;46(5):226-32.

14. Spindola T, Santos RS. Trabalho versus vida em família: conflito e culpa no cotidiano das trabalhadoras de enfermagem. Cienc Enferm. 2004;10(2):43-52.

15. Fernandes JD, Ferreira SL, Albergaria AK, Conceição FM. Saúde mental e trabalho feminino: imagens e representações de enfermeiras. Rev Latinoam Enfermagem. 2002;10 (2):199-206.

16. Farias SNP, Mauro MYC, Zeitoune RCG. Questões legais sobre a saúde do trabalhador de enfermagem. Rev Enfermagem UERJ. 2000;8(1):28-32.

17. Xelegati R, Robazzi MLCC. Riscos químicos a que estão submetidos os trabalhadores de enfermagem: uma revisão de literatura. Rev Latinoam Enfermagem. 2003;11(3):350-6.

18. Pafaro RC, De Martino MMF. Estudo do estresse do enfermeiro com duplajornada de trabalho em um hospital de oncologia pediátrica de Campinas. Rev Esc Enfermagem USP. 2004;38(2):152-60.

19. Pereira WR, Silva GB. A mulher, o trabalho e a enfermagem profissional: algumas reconsiderações sob a ótica do gênero. Texto \& Contexto Enfermagem. 1997;6(1):18-32.

20. Stacciarini JMR, Tróccoli BT. O estresse na atividade ocupacional do enfermeiro. Rev Latinoam Enfermagem. 2001;9(2):17-25.

21. Foucault M. Microfísica do poder. 10a ed. Rio de Janeiro: Graal; 1992.

22. Gelain I. O enfermeiro e suas atribuições "de poder" nas relações de trabalho. Cogitare Enferm. 1996;1(2):70-4.

23. Bretas $\mathrm{ACP}$. $\mathrm{O}(\mathrm{A})$ enfermeiro(a) e a política: questões para reflexão [editorial]. Acta Paul Enfermagem. 2003;16 (2):5.

24. Batista AAV, Vieira MJ, Cardoso NCS, Carvalho GRP. Fatores de motivação e insatisfação no trabalho do enfermeiro. Rev Esc Enfermagem USP. 2005;39(1):85-91.

25. Rossi FR, Lima MADS. Fundamentos para processos gerenciais na prática do cuidado. Rev Esc Enfermagem USP. 2005;39(4):460-8.

26. Arendt H. A condição humana. 10a ed. Rio de Janeiro: Forense-Universitária; 2005. 